\title{
Resenha
}

Retratos do mal-estar contemporâneo na educação

Rinaldo Voltolini

São Paulo: Escuta/Fapesp, 2014, 236p.

\section{TRATAMENTOS POSSÍVEIS AO IMPOSSÍVEL DA EDUCAÇÃO}

\author{
Daniela Teperman \\ DOI: http://dx.doi.org/10.11606/issn. 1981-1624.v19i3p515-518
}

Retratos do mal-estar contemporâneo na educação não é um título casual. A ideia de retrato serve para marcar aquilo que é pretensão de congelar o tempo, de fixar alguma coisa que resista a sua fluidez. Condensa, portanto, aquilo que é o gosto neurótico pela nostalgia e a constatação de um mundo no qual a solidez e a durabilidade das coisas parece se desvanecer rapidamente ${ }^{1}$.

Em “O mal-estar na civilização”, texto de 1929, Freud (1981) demonstrou como civilização é mal-estar, abandonando definitivamente a ilusão de uma harmonia possível entre o indivíduo e o social. No mesmo texto o autor sublinhou que a educação não prepara as crianças para enfrentar a vida: "Ao encaminhar os jovens para a vida com essa falsa orientação psicológica, a educação se comporta como se devesse equipar pessoas que partem para uma expedição polar com trajes de verão e mapas de lagos italianos" (Freud, 1929/1981, p. 3060). A leitura desse pequeno trecho poderia dividir o leitor: será que ali Freud situou o que é estrutural na educação ou fez uma crítica ao modo como se educava na sua época? Penso que o psicanalista

- Psicanalista. Doutora em Psicanálise e Educação pela Faculdade de Educação da Universidade de São Paulo (FEUSP), São Paulo, SP, Brasil. 
deu um tratamento aos dois aspectos, ao estrutural, ao explicitar que educação é mal-estar, e ao que é da ordem da contingência, ou a forma que o educar assume em cada época diante do mal-estar que é a educação.

De acordo com Pujó (2006), uma época se define como "uma resposta específica e elaborada em determinado contexto histórico pela civilização, ao que Lacan formula como a ausência de relação sexual” (p. 62, tradução livre). Assumindo que a desarmonia nos é estrutural, podemos também pensar cada época como a articulação de modos particulares de fazer frente ao mal-estar. Quando nos concentramos no campo da educação, cabe questionar-nos a respeito de como em nossa época o mal-estar inerente à educação se particulariza e, no mesmo movimento, que leituras um psicanalista pode propor diante do mal-estar na educação de sua época, pois, como bem nos lembra Sauret (1998), se o psicanalista não escolhe o lugar em que se impõe, o pedido social - lugar em que é demandado - pode, sim, escolher a sua resposta.

No campo da educação, é frequente que diante do impossível o que se produza seja a impotência. Assim, encontramos do lado de gestores, professores e educadores, queixas em relação às famílias das crianças, à falta de recursos ou de formação específica ou à sobrecarga decorrente da presença de crianças ditas "difíceis" ou dos chamados "casos de inclusão". Deste modo, o espaço que se abre diante do

516 Estilos clin., São Paulo, v. 19, n. 3, set./dez. 2014, 515-518. 
impossível, ao invés de produzir respostas singulares, passíveis de serem aplicadas no caso a caso, ou de habilitar a invenção, como se poderia esperar, produz impotência, queixa e desimplicação.

A impotência vem muitas vezes acompanhada de nostalgia e saudosismo. Se tomamos o campo da família como exemplo, é fácil explicar a que me refiro. Diante das transformações e das novas configurações familiares, não é raro encontrarmos um discurso alarmista (estaríamos em uma crise sem precedentes) e/ou saudosista (como se a família tradicional representasse alguma garantia na criação das crianças, ou como se a operatividade da função paterna fosse uma decorrência natural do patriarcado).

Os autores reunidos por Rinaldo Voltolini no livro Retratos do mal-estar contemporâneo na educação responderam à convocação implicada no título proposto e produziram os textos que integram a coletânea, tratando de temas como a autoridade, a relação escola-família, a inclusão, a filiação e a transmissão. Ao contrário do que costuma ocorrer em uma produção como um livro, em que o texto já existe e o título é acrescentado a ele, neste caso foi a partir do título que se pretendeu suscitar uma produção.

Além do fato de que na referida coletânea a escolha do título tenha antecedido a produção e, mais que isso, tenha pretendido provocá-la, há um outro aspecto a ser destacado: os autores ali reunidos são psicanalistas ou orientam suas pesquisas a partir do referencial psicanalítico. Com isso quero dizer que a orientação psicanalítica implica uma particularidade na autoria dos textos. Acrescento ainda que, para além da particularidade decorrente da orientação psicanalítica, o leitor encontrará nos artigos a marca da singular relação de cada autor com seu objeto de pesquisa e a partir dos autores com os quais dialoga.

No discurso do psicanalista o objeto causa do desejo está no lugar de agente, de forma que o autor que se posiciona desta maneira diante de uma convocação pode produzir um saber a partir do lugar em que se vê causado a trabalhar. A particularidade da orientação psicanalítica permite que encontremos autores capazes de produzir furos nos discursos prevalecentes na atualidade, e, advertidos dos riscos implicados na nostalgia de um passado mítico e da paralisação produzida pela impotência, podem se concentrar em tratamentos possíveis diante do impossível estrutural da educação.

Assim, a vivacidade de Retratos do mal-estar contemporâneo na educação reside no fato de estarmos diante de uma coletânea em que os autores 
testemunham acerca do modo pelo qual a convocação os causou a partir de seus temas de pesquisa e investigação e dos autores com os quais estabelecem uma interlocução. $\mathrm{O}$ livro se constitui, desta forma, em um bom exemplo do que pode ocorrer quando as leituras do mal-estar (do lado da estrutura) se particularizam em produções que trazem a marca singular do modo pelo qual cada autor foi tocado pelo tema em questão (do lado da contingência).

\section{REFERENNCIAS}

Freud, S. (1981). El malestar en la civilización. In S. Freud, Obras Completas (Vol. III, pp. 3017-1067). Madrid: Editorial Biblioteca Nueva. (Trabalho original publicado em 1929)

Pujó, M. (2006). Para una clinica de la cultura. Buenos Aires: Grama Ediciones. Sauret, M. J. (1998). O infantil \& a estrutura. São Paulo: Escola Brasileira de Psicanálise.

\section{NOTA}

1. Texto de abertura do $99^{\circ}$ Colóquio Internacional do LEPSI / $4^{\circ}$ RUEPSY $\mid$ Retratos do mal-estar contemporâneo na educação | 18/10/2012 - 20/10/2012.

danitep@usp.br

Rua Ferreira de Araújo, 385 05428-000 - São Paulo - SP - Brasil.

Recebido em agosto/2014. Aceito em setembro/2014.

518 Estilos clin., São Paulo, v. 19, n. 3, set./dez. 2014, 515-518. 